\title{
Leadership Styles and Productivity
}

\author{
Shweta Tewari ${ }^{1}$, Rajashree Gujarathi ${ }^{1}$, \& K. Maduletty ${ }^{1}$ \\ ${ }^{1}$ S.P Jain School of Global Management, Mumbai, India \\ Correspondence: Shweta Tewari, S.P Jain School of Global Management, Mumbai, India. Tel: 91-99-1630-2504. \\ E-mail: shweta.dbaff01031@spjain.org
}

Received: January 4, 2019

doi:10.5539/ass.v15n4p115
Accepted: March 8, 2019 Online Published: March 29, 2019

URL: https://doi.org/10.5539/ass.v15n4p115

\begin{abstract}
Leadership styles in today's world is an increasingly complex and a popular organizational dynamic to work upon. Different leadership styles are appropriate in distinct situations. If an inappropriate style is adopted by the leader, it may pose several challenges for the workers, managers and human resources departments in the planning and execution of work in an organization. Similarly, the satisfaction and performance levels of employees also depend upon the leadership styles adopted by corporate leaders. An appropriate leadership style paves way to delivering successful plans for fulfilling the long-term organizational goals. Little is however understood about which leadership style influence employees the most and how leadership behavior lead to acceptable outcomes. This paper reviews some of the current challenges in organizations which are faced by managers and the productivity levels for the same. This research statistically calculates and analyzes the leadership style of 50 respondents and which category they fall into depending upon their behavioral attributes to deal with people through a survey questionnaire of 25 questions. It further helps us conclude which leadership style is the most relevant for highest level of productivity in telecommuting employees and managers. It also gives an insight on managerial behaviors and relationship of employees and managers in a less formal organizational setup.
\end{abstract}

Keywords: leadership behavior, leadership styles, telecommuting, productivity

\section{Introduction}

\subsection{Introduction to the Problem}

Administrators play a pivotal role in influencing worker efficiency and achievement. Past research has distinguished hierarchical structure (Karen R. Kemerling).

\subsection{Importance of the Problem}

Mental cooperation is a critical factor for a strong connection between transformational leadership style and remote worker's intention to leave an association. Further the more a leader shows a transformational authority style, the more a remote worker wishes to leave the association with regards to investigating productivity and duty which are related. Findings demonstrate that a noteworthy negative relationship is between free enterprise initiative style and expectation to leave an organization. The more a leader shows a free enterprise administration style, the less a remote worker wishes to leave the association. Further No relationship existed between apparent value-based initiative style and remote worker purpose to leave an association (Overbey). (Huntsville) Further dissected that administrators in the virtual work environment are occupied undertaking focused style more than socially arranged initiative style. Likewise, administration bridges in as the best indicator of the correspondence fulfillment, work fulfillment, and the hierarchical responsibility of remote workers. So as to bridge out these conceivable contrasts in innovation, future scientists might need to gather a larger dataset and think about the authority styles and correspondence of managers. The work environment keeps on changing, and the requirement for research to address these progressions is steady. The reason for this paper is to examine and inquire about around there to decide whether authority styles and profitability are changing in light of the social changes that we are starting to find in the congenial work environment of working from home. This paper will audit past research to: (1) Determine if there are administration styles that are identified with profitability and the examination done on the equivalent and (2) Investigate the connection between which leadership style will influence productivity more. 


\subsection{Relevant Scholarship}

The successful implementation of a telecommuting program is achieved by placing apt Human resource policies and leadership guiding and managing the process adequately. The best telecommuting policies are those which are designed to meet a company's needs and fit the company's culture (Alexandria et al.) suggests situational leadership as one of the styles to influence off site workers. An organization's implementation and provision of telework arrangement becomes more influencing and widespread to all its levels when it is supported by top leaders of the organization who believe in work -family balance, even after keeping in control the firm's context, industry, geographical distribution, size. More importantly the authors also find that managerial beliefs adds to or increases the positive effect of instrumental factors on the provision of home telework. From the point of viewpoint of practitioners for whom contextual and organizational features are an important choice, corporate social responsibilities for employees and the society at large, the conviction of the top management or senior leaders becomes essential (Mayo et al.). Further research suggests that support variables are also essential in successful implementation of telecommuting practices. Research also shows some evidence of an interaction effect between personal nature and characteristics, supervisor's or leaders support and family support. Another study investigated the relationship between different forms of organization support classified as technology related, somewhat technology related, non technological and employee's reaction to it. A non technological variables-managers trust and two technology related variables were chosen and it reflected that it had a broader impact on employee's reactions to telecommuting. Hence technology plays a crucial role. Results also indicate that organizations should concentrate on providing IT support constantly and appropriate technology assisted environment for telecommuters as well as a specific telecommuting related training for non-telecommuting coworkers and managers so that the productivity of them is higher and the results are effective. (Baker, Avery, \& Crawford) However, telecommuting will remain a popular form of a flexible work arrangement. There are emerging societal and ethical issues that also remain unanswered. (Crandall \& Gao)

\section{Research Methodology}

\subsection{Variables of the Study}

The variables used in the study were:

- Leadership styles as independent variable

Directing

Coaching

Delegating

Facilitating

- Productivity as dependent variable

\subsection{Participant Characteristics}

- Gender-both male and female

- $\quad$ Profile of respondent-Information Technology Working professionals

\subsection{Sampling Procedure and Sample Size}

- Sample size-50 respondents

- Method-Web based questionnaire

- Questionnaire Size-25 questions

- Random sampling method

\subsubsection{Research Design}

- Participants were observed naturalistically.

- There were no multiple conditions that were created.

- A within subject / repeated measures study design was used.

\section{Results}

3.1 Statistics and Data Analyses

The Impact of Leadership Style on Productivity 


\section{number of respondents}

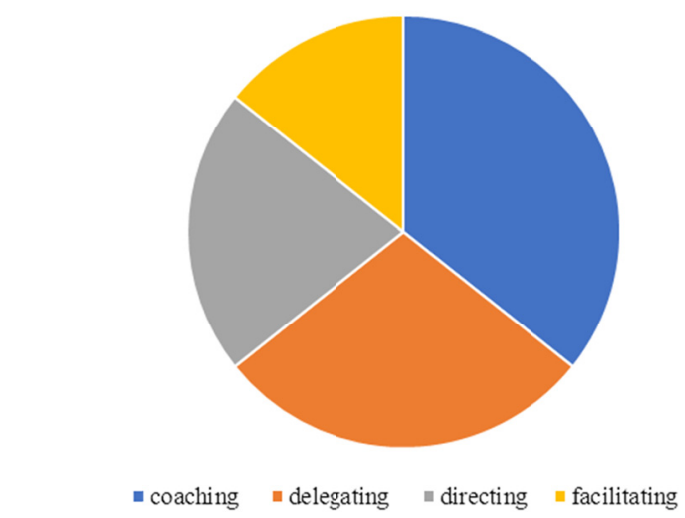

Figure 1.

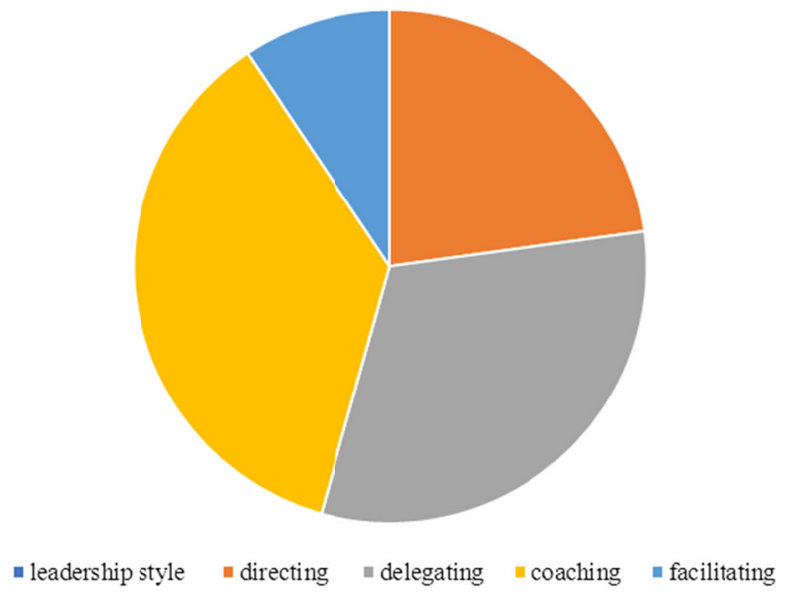

Figure 2.

Figure 1 shows the number of respondents in each style category.it helps us understand the profile of maximum respondents and which category they fall into.

Figure 2 shows the relationship between productivity and leadership style of respondents. Here we see how maximum respondents have coaching skills and have reported higher levels of productivity of their staff. Followed by delegating which reports the second highest level in the chart. The third being directing followed by facilitating.

\section{Discussion}

We can thus conclude that maximum respondents who were satisfied with the productivity of their staff possessed coaching leadership style and that it can be a lead to future research to explore further into the scope of other leadership styles and its relationship with productivity from different angles.

Practically we see many organizations which fail in implementing the telecommuting system due to various reasons, the manager subordinate relationship being the major possible reason for the failure in implementation. We understand that every manager is possessed with a certain set of skills and possess a leadership style which we refer to as the "style of work", when we compare such with productivity we observe the difference in outcomes of different teams and their managers. Through this research-based study we can think of applying the coaching skill which led to higher productivity in the studied sample of telecommuters and their respective managers. Future studies can further explore the same through a higher sample size in a larger organization by comparing it to relevant issues which will evolve in the coming years and get solutions relevant for the same, as business is a complex environment, the problems which evolve are ever changing.

\section{References}

Sonia, K. What is leadership? Retrieved from http://www.managementstudyhq.com/types-of-leadership.html 
Ahmed, R. (2017). 12 Different types of Leadership styles. Retrieved from http://wisetoast.com/12-differenttypes-of-leadership-styles/

Terry, S. (2017). Leadership qualities from 'The Wizard of $O z$ '. Retrieved from http://www.ibmadison.com/ Blogger/Leader-to-Leader/November-2017/Leadership-qualities-from-The-Wizard-of-Oz/index.php?cpartic $1 \mathrm{e}=1 \&$ siarticle $=0$ \#artanc

Deep, P. (2017). 8 proven ways to increase your productivity as a leader. Retrieved from https://www.forbes.com/sites/deeppatel/2017/10/27/8-proven-ways-to-increase-your-productivity-as-a-leade $\mathrm{r} / \# 605408297 \mathrm{be} 4$

Kimberlee, L. (2018). Leadership style influence organizational productivity. Retrieved from $\mathrm{http}: / /$ smallbusiness.chron.com/leadership-style-influence-organizational-productivity-11643.html

Marcel, G. de. (2016). Effective leadership: The key to productivity and well-being. Retrieved from http://management-training-coaching.ch/?p=118

Anbazhagan, S., \& Bhargava, K. R. (2014). Worker productivity, leadership style relationship. IOSR Journal of business and management. Retrieved from http://iosrjournals.org/iosr-jbm/papers/Vol16-issue8/Version-4/ H016846270.pdf

Preetham, G. (2008). Significance of leadership in productivity management. Proceedings of the International Multi Conference of Engineers and Computer Scientists. Retrieved from https://pdfs.semanticscholar.org/ 3d4e/4cdeb36864755aa75eac286bc820f8f12c03.pdf

Shalu, M. (2015). Impact of leadership on employee productivity. International Journal of Engineering Technology Science and Research. Retrieved from http://www.ijetsr.com/images/short_pdf/1448542032 134-138_TSMI267_ijetsr.pdf

Belas, J. (2013). The leadership style and productiveness of employees in banking sector in Slovakia. Journal of competitiveness. Retrieved from http://www.cjournal.cz/files/124.pdf

Igbaekemen, G. (2015). Impact of leadership style on organization performance. Arabian Journal of Business and Management Review. Retrieved from https://www.omicsonline.org/open-access/impact-of-leadershipstyle-on-organization-performance-a-critical-literature-review-2223-5833-1000142.pdf

Satish, M., \& Joyce, H. M. (1999). Management leadership and productivity improvement programs. International Journal of Applied Quality Management. Retrieved from https://www.sciencedirect.com/ science/article/pii/S1096473899800918

\section{Copyrights}

Copyright for this article is retained by the author(s), with first publication rights granted to the journal.

This is an open-access article distributed under the terms and conditions of the Creative Commons Attribution license (http://creativecommons.org/licenses/by/4.0/) 